\title{
Optimization of Boring Process Parameters in Manufacturing of Polyacetal Bushing using High Speed Steel
}

\author{
The Jaya Suteja ${ }^{1, *}$, Yon Haryono ${ }^{1}$, Andri Harianto $^{1}$, and Esti Rinawiyanti ${ }^{2}$ \\ ${ }^{1}$ Manufacturing Engineering, University of Surabaya, Surabaya, Indonesia \\ ${ }^{2}$ School of Management, College of Business, Royal Melbourne Institute of Technology, Melbourne, \\ Australia
}

\begin{abstract}
Polyacetal is commonly used as bushing material because of its low coefficient of friction and self lubricant characteristics. The polyacetal is machined by using boring process to produce bushing in certain surface roughness. The objectives of this research are to optimize three independent parameters (depth of cut, feed rate and principal cutting edge angle) of boring process of polyacetal using high speed steel tool to achieve the highest material removal rate and the required surface roughness. Response Surface Methodology is used to investigate the influence of the parameters and optimize the boring process. The research shows that the influence of the boring process parameters on polyacetal is similar compared to on metal. The result reveals that the optimum result is achieved by applying the value of depth of cut, feed rate, and principal cutting edge angle is $2.9 \times 10^{-3} \mathrm{~m}, 0.229 \mathrm{~mm} \mathrm{rev}^{-1}$, and $99.1^{\circ}$ respectively. By applying these values, the maximum material rate removal achieved in this research is $1263.4 \mathrm{~mm}^{3} \mathrm{~s}^{-1}$ and the surface roughness achieved is $1.57 \times 10^{-6} \mathrm{~m}$.
\end{abstract}

Keywords: machine, material rate removal, maximization, surface roughness, tool steel.

\section{Introduction}

Polyacetal or polyoxymethylene or polyformaldehyde is an engineering thermoplastic that has abrasion and wear resistance, low friction coefficient, good stiffness and hardness, dimensional stability, fatigue and impact strength, and creep resistance [1]. It can be used as various products or parts such as toys, fans, and bushings. It is commonly used as a bushing because of its low friction coefficient and self lubricant characteristics.

Polyacetal bushing is manufactured using boring process to achieve the required shape, dimension, and surface roughness. In order to achieve the shortest manufacturing time, the material removal rate must be set as high as possible. However, maximum removal rate will increase the

\footnotetext{
${ }^{*}$ Corresponding author: jayasuteja@staff.ubaya.ac.id
} 
surface roughness. Parameters of boring process that influence the material removal rate and the surface roughness are tool material, tool radius, tool geometry, depth of cut, feed rate, cutting speed, principal cutting edge angle, tool overhang, job length, and coolant.

Beauchamp et al. [2] investigate the influence of cutting speed at $1.67 \mathrm{~m} \mathrm{~s}^{-1}$ to $2.5 \mathrm{~m} \mathrm{~min}^{-1}$, feed rate at $0.075 \mathrm{~mm} \mathrm{rev}^{-1}$ to $0.105 \mathrm{~mm} \mathrm{rev}^{-1}$, depth of cut at $25 \times 10^{-5} \mathrm{~m}$ to $75 \times 10^{-5} \mathrm{~m}$, tool nose radius at $3.969 \times 10^{-4} \mathrm{~m}$ and $7.938 \times 10^{-4} \mathrm{~m}$, tool length $65.09 \times 10^{-3} \mathrm{~m}$ and $95.25 \times 10^{-3} \mathrm{~m}$, and the type of boring bar of boring operation to surface roughness of carbon steel AISI 1026 material using cemented carbide tool [2]. The research shows that the increase of the feed rate, cutting speed, and tool nose radius will increase the surface roughness of the manufactured material. The longer tool will also increase the surface roughness. Meanwhile, the increase of the depth of cut will decrease the surface roughness.

Similar research has been conducted by Vohra, et al. [3], Vaishnav and Sonawane [4], Borade and Deshmukh [5], Kumar, et al. [6], Panyaphirawat et al. [7], and Chennu, et al. [8]. Their research show that feed rate, cutting speed and depth of cut influence the surface roughness and material rate removal of various metal materials.

Rico, et al. [9] and Mohammad, et al. [10] investigate the influence of tool geometry such as the cutting edge angle in turning process to the surface roughness of various metal materials using carbide tool. They conclude that the cutting edge angle will influence the surface roughness of the material. Karim et al. [11] in their research report add that the increase of the rake angle will decrease the value of the surface roughness in the turning process of aluminium material using High Speed Steel tool.

Other researchers conduct investigation on the influence of boring parameters on the surface roughness and material rate removal of polyacetal material. [12] investigates the influence of feed rate at $0.08 \mathrm{~mm} \mathrm{rev}^{-1}$ to $0.12 \mathrm{~mm} \mathrm{rev}^{-1}$, depth of cut at $3 \times 10^{-4} \mathrm{~m}$ to $1 \times 10^{-3} \mathrm{~m}$, and cutting speed at $1.5 \mathrm{~m} \mathrm{~s}^{-1}$ to $2.167 \mathrm{~m} \mathrm{~s}^{-1}$ to polyacetal material using TiN coated carbide. According to the research, the increase of feed rate, depth of cut, and cutting speed will increase the surface roughness and material rate removal. In addition Sugiantoro [13] also conducted an investigation on the influence of depth of cut at $1.2 \times 10^{-3} \mathrm{~m}$ to $1.6 \times 10^{-3} \mathrm{~m}$, nose radius at $4 \times 10^{-4} \mathrm{~m}$ to $12 \times 10^{-4} \mathrm{~m}$, rake angle at $1^{\circ}$ to $5^{\circ}$, and the use of coolant to the surface roughness and material rate removal of polyacetal using tungsten carbide. This research shows that the increase of rake angle value will decrease the material rate removal and the surface roughness of polyacetal. Meanwhile the nose radius has negative correlation with surface roughness and positive correlation with material rate removal. The increase of depth of cut will increase the material rate removal and the surface roughness. Finally, the use of the coolant will decrease the surface roughness but has no influence on the material removal rate.

None of previous studies found in the literature investigates nor optimized the influence of boring process parameters and tool geometry on the material rate removal and surface roughness of polyacetal material using High Speed Steel (HSS). Even though carbide tool has more superior characteristics compare to HSS such as wear resistance and material strength, it is considered more expensive compared to HSS for machining softer material such as polyacetal. For example, carbide tool will be able to retain its hardness at high temperature but this will not bring any advantage in the boring process of polyacetal because the process will not reach this temperature. In addition, tools for plastic machining must always be well sharpened and smooth to achieve a good surface quality. In this case, HSS is better compare than carbide tool because it is softer and easy be sharpened.

To increase the productivity in manufacturing process of polyacetal bushing, it is important to investigate whether the influence of boring process parameters and HSS tool geometry on material rate removal and surface roughness of polyacetal will be similar compared to their influence on material rate removal and surface roughness of metal and then optimize the parameters. Applying deeper depth of cut, faster feed rate, and higher degree of principal cutting edge angle of boring process will increase the material removal rate and at the same time increase surface roughness of metal [14]. The first objective of this research is to verify whether 
the depth of cut, feed rate, and principal cutting edge angle of boring process have the same influence on material rate removal and surface roughness of polyacetal and metal. The next objective of this research is to optimize these three boring parameters to achieve the maximum material rate removal and the required surface roughness of polyacetal material using HSS tool.

\section{Research design}

The boring process in this research is conducted by using CNC turning machine HITACHI HT20S11 with HSS tool and water coolant. The cutting speed is set to $3.83 \mathrm{~m} \mathrm{~s}^{-1}$ according to the tool and the work piece type. The tool has end relief angle $70^{\circ}$, nose radius $4 \times 10^{-4}$ $\mathrm{m}$, rake angle $0^{\circ}$, and end cutting edge angle $10^{\circ}$. The tools dimension is designed according to the recommendation of $[14,15]$.

Three boring process parameters, which are depth of cut, feed rate, and principal cutting edge angle, are determined as the factors to achieve the value of two responses, which are material rate removal (MRR) and surface roughness (Ra). The achieved value of the MRR must be as maximum as possible but the value of the Ra must not exceed $1.6 \times 10^{-6} \mathrm{~m}$. The maximum value of $\mathrm{Ra}$ is determined according to the general surface roughness of bushing.

MRR is calculated by dividing the removed volume of the polyacetal work piece with the cutting time. The final dimension of the work piece is a cylinder with $25 \times 10^{-3} \mathrm{~m}$ diameter and $28 \times 10^{-3} \mathrm{~m}$ length. The initial diameter of the work piece is the final diameter plus the varied depth of cut according to each experiment. To measure the cutting time, a stop watch with $0.01 \mathrm{~s}$ accuracy is used. A calliper with $1 \times 10^{-5} \mathrm{~m}$ accuracy is used to measure the dimension of the work piece. The surface roughness of the work piece is measured by using Mitutoyo surface roughness equipment with $1 \times 10^{-8} \mathrm{~m}$ accuracy.

In order to investigate the influence of depth of cut, feed rate, and the principal cutting edge angle of boring process to the MRR and $\mathrm{Ra}$, a factorial design method is applied. To obtain independent error estimation, the factorial design is augmented with five centre points. Then, response surface methodology is employed to optimized those three boring process parameters in order to achieve the maximum MRR without exceed $1.6 \times 10^{-6} \mathrm{~m}$ of Ra.

Several preliminary experiments have been conducted in order to generate the equation of Ra and MRR. According to the analysis of variant (ANOVA) result, the equations of Ra and MRR have been indicated not linear. As, there is indication of quadratic effects then the five levels of factor are implemented. Based on the literature review and the preliminary experiments, the value of each factor level is determined as shown in Table 1.

In this research the cutting temperature is assumed constant. It is assumed that the tool deflection and tool wear do not influence the surface roughness of the work piece. The work piece is assumed homogenous.

Table 1. Value of each factor level.

\begin{tabular}{|c|c|c|c|c|c|}
\hline Factor & $\begin{array}{c}\text { Lowest } \\
\mathbf{( - 1 . 6 8 1})\end{array}$ & $\begin{array}{c}\text { Low } \\
(\mathbf{- 1 )}\end{array}$ & $\begin{array}{c}\text { Middle } \\
(\mathbf{0})\end{array}$ & $\begin{array}{c}\text { High } \\
\mathbf{( 1 )}\end{array}$ & $\begin{array}{c}\text { Highest } \\
(\mathbf{1 . 6 8 1})\end{array}$ \\
\hline Depth of Cut $(\mathrm{m})$ & $1.9 \times 10^{-3}$ & $2.1 \times 10^{-3}$ & $2.4 \times 10^{-3}$ & $2.7 \times 10^{-3}$ & $2.9 \times 10^{-3}$ \\
\hline Feed Rate $\left(\mathrm{mm} \mathrm{rev}^{-1}\right)$ & 0.166 & 0.18 & 0.20 & 0.22 & 0.234 \\
\hline Principal Cutting Edge Angle $\left(^{\circ}\right)$ & 73.2 & 80 & 90 & 100 & 106.8 \\
\hline
\end{tabular}

\section{Results and discussion}

In this research, the experiment is designed to conduct $2^{3}$ (two cubed) with five centres runs and then added with six factorial runs in order to fit the second order or quadratic model. 
Based on the experiment, the values of $\mathrm{Ra}$ and MRR for each level of factor are shown in Table 2 below.

The experiment result is processed by using statistical software to develop the prediction of equation model for Ra and MRR. The best model is chosen when it has the minimum square root of the residual mean square and the maximum amount of variation around the mean with a condition that calculated probability value must be less than 0.05 . The coefficients for the best model of Ra and MRR shown in Figure 1 are used to develop the $\mathrm{Ra}$ and MRR equations. Then, the developed equation models are tested to verify whether they are the best model and fit to predict Ra and MRR. Based on the experiment result, the best model for Ra and MRR are shown in Equation 1 and Equation 2 respectively where D is Depth of Cut $(\mathrm{m}), \mathrm{f}$ is Feed Rate $\left(\mathrm{mm} \mathrm{rev}^{-1}\right)$ and $\mathrm{K}$ is Principal Cutting Edge Angle $\left(^{\circ}\right)$.

Table 2. Experiment result.

\begin{tabular}{|c|c|c|c|c|}
\hline \multicolumn{3}{|c|}{ Factor Value } & \multicolumn{2}{|c|}{ Response Value } \\
\hline $\begin{array}{l}\text { Depth of Cut } \\
\left(\times 10^{-3} \mathrm{~m}\right)\end{array}$ & $\begin{array}{l}\text { Feed Rate } \\
\left(\mathrm{mm} \text { rev }^{-1}\right)\end{array}$ & $\begin{array}{c}\text { Principal Cutting } \\
\text { Edge Angle } \\
\left({ }^{\circ}\right)\end{array}$ & $\begin{array}{c}\text { Ra } \\
\left(\times \mathbf{1 0}^{-6} \mathrm{~m}\right)\end{array}$ & $\begin{array}{c}\text { MRR } \\
\left(\times 10^{-9} \mathrm{~m}^{3} \mathrm{~s}^{-1}\right)\end{array}$ \\
\hline 2.1 & 0.18 & 80 & 0.94 & 741.73 \\
\hline 2.7 & 0.18 & 80 & 0.84 & 788.18 \\
\hline 2.1 & 0.22 & 80 & 1.11 & 866.37 \\
\hline 2.7 & 0.22 & 80 & 1.13 & 929.94 \\
\hline 2.1 & 0.18 & 100 & 1.06 & 743.78 \\
\hline 2.7 & 0.18 & 100 & 1.09 & 926.28 \\
\hline 2.1 & 0.22 & 100 & 1.57 & 881.64 \\
\hline 2.7 & 0.22 & 100 & 1.66 & 1132.6 \\
\hline 1.9 & 0.20 & 90 & 0.73 & 754.15 \\
\hline 2.9 & 0.20 & 90 & 0.74 & 1105.5 \\
\hline 2.4 & 0.166 & 90 & 0.56 & 743.50 \\
\hline 2.4 & 0.234 & 90 & 1.2 & 1146.9 \\
\hline 2.4 & 0.20 & 73.2 & 0.91 & 938.69 \\
\hline 2.4 & 0.20 & 106.8 & 1.63 & 936.50 \\
\hline 2.4 & 0.20 & 90 & 0.77 & 914.90 \\
\hline 2.4 & 0.20 & 90 & 0.79 & 916.31 \\
\hline 2.4 & 0.20 & 90 & 0.77 & 910.96 \\
\hline 2.4 & 0.20 & 90 & 0.78 & 910.58 \\
\hline 2.4 & 0.20 & 90 & 0.76 & 911.54 \\
\hline
\end{tabular}

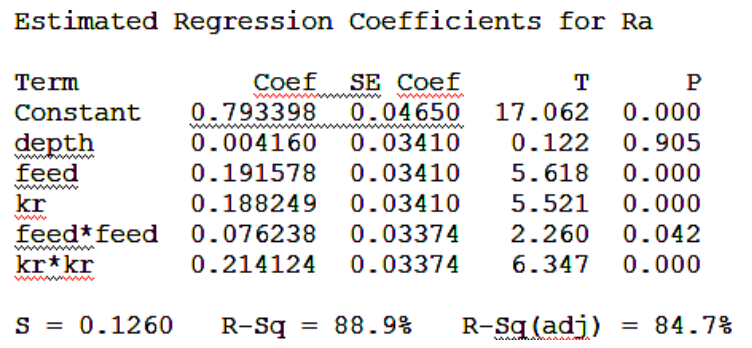




$\begin{array}{lrrrr}\text { Estimated Regression Coefficients } & \text { for MRR } \\ \text { Term } & \text { Coef } & \text { SE Coef } & \text { T } & \text { P } \\ \text { Constant } & 905.00 & 11.30 & 80.117 & 0.000 \\ \text { depth } & 82.70 & 13.32 & 6.207 & 0.000 \\ \text { feed } & 94.02 & 13.32 & 7.057 & 0.000 \\ \text { kr } & 26.32 & 13.32 & 1.975 & 0.068 \\ \text { depth*kr } & 41.06 & 17.41 & 2.358 & 0.033 \\ \text { S }=49.24 & \text { R-Sq }=87.5 \% & \text { R-Sq(adj) }=83.9 \%\end{array}$

Fig. 1. Coefficients of the best model for Ra and MRR.

$$
\begin{gathered}
\mathrm{Ra}=0.793398+0.004160 \mathrm{D}+0.191578 \mathrm{f}+0.188249 \mathrm{~K}+0.076238 \mathrm{f}^{2}+0.214124 \mathrm{~K}^{2} \\
\operatorname{MRR}=905+82.7 \mathrm{D}+94.02 \mathrm{f}+26.32 \mathrm{~K}+41.06 \mathrm{D} . \mathrm{K}
\end{gathered}
$$

The Equation 1 shows that the increase of the depth of cut, feed rate, and principal cutting edge angle will increase the surface roughness. Based on the Equation 2, it can be predict that the material rate removal will be increased when the depth of cut, feed rate, and principal cutting edge angle are increased. These equations show that the depth of cut, feed rate, and principal cutting edge angle of boring process have the same influence on material rate removal and surface roughness of polyacetal and metal.

Before optimizing the optimized the depth of cut, feed rate, and principal cutting edge angle to achieve the maximum material rate removal and the required surface roughness, the residual test must be conducted. The test indicates both equations fulfil the requirement in order to perform the optimization.

The response optimizer of the statistical software shows that the optimum point for surface roughness and material rate removal are achieved when the value of depth of cut, feed rate, and principal cutting edge angle are set $2.9 \times 10^{-3} \mathrm{~m}, 0.229 \mathrm{~mm} \mathrm{rev}^{-1}$, and $99.1^{\circ}$ respectively. The maximum material removal achieved by implementing these parameter values is $1269.72 \times 10^{-9} \mathrm{~m}^{3} \mathrm{~s}^{-1}$. In the same time, the achieved surface roughness is 1.599 $\times 10^{-6} \mathrm{~m}$.

In order to verify whether the predicted equations can be used to achieve the optimum surface roughness and material rate removal, a confirmation test experiment is conducted. The result of the confirmation test experiment is shown in Table 3. As shown in Table 3, the average maximum material rate removal is $1263.4 \times 10^{-9} \mathrm{~m}^{3} \mathrm{~s}^{-1}$ and the average achieved surface roughness is $1.57 \times 10^{-6} \mathrm{~m}$. Therefore, the result of the response optimizer can be used to estimate the optimum point for surface roughness and material rate removal.

Table 3. Result of confirmation test.

\begin{tabular}{|c|c|c|c|c|}
\hline $\begin{array}{c}\text { Depth of Cut } \\
\left(\times \mathbf{1 0}^{-\mathbf{3}} \mathbf{~ m}\right)\end{array}$ & $\begin{array}{c}\text { Feed Rate } \\
\left(\mathbf{m m} \mathbf{~ r e v}^{-1}\right)\end{array}$ & $\begin{array}{c}\text { Principal Cutting Edge Angle } \\
(\mathbf{(})\end{array}$ & $\begin{array}{c}\text { Ra } \\
\left(\times \mathbf{1 0}^{-\mathbf{6}} \mathbf{~}\right)\end{array}$ & $\begin{array}{c}\text { Maximum MRR } \\
\left(\times \mathbf{1 0}^{-\mathbf{9}} \mathbf{~ m}^{\mathbf{3}} \mathbf{~ s}^{\mathbf{1}}\right)\end{array}$ \\
\hline 2.9 & 0.229 & 99.1 & 1.57 & 1259 \\
\hline 2.9 & 0.229 & 99.1 & 1.58 & 1264 \\
\hline 2.9 & 0.229 & 99.1 & 1.56 & 1265.5 \\
\hline 2.9 & 0.229 & 99.1 & 1.59 & 1264.5 \\
\hline 2.9 & 0.229 & 99.1 & 1.59 & 1259.7 \\
\hline 2.9 & 0.229 & 99.1 & 1.54 & 1267.4 \\
\hline
\end{tabular}




\section{Conclusions}

This research reveals that the influence of the depth of cut, feed rate, and principal cutting edge angle of boring process on the surface roughness and the material rate removal of polyacetal bushing is similar compared to their influence on metal. The result of this research also shows that the achieved maximum material removal rate is $1263.4 \times 10^{-9} \mathrm{~m}^{3}$ $\mathrm{s}^{-1}$. The maximum material removal rate is achieved when the value of depth of cut, feed rate, and principal cutting edge angle are set $2.9 \times 10^{-3} \mathrm{~m}, 0.229 \mathrm{~mm} \mathrm{rev}^{-1}$, and $99.1^{\circ}$ respectively. At this condition, the achieved surface roughness is $1.57 \times 10^{-6} \mathrm{~m}$.

\section{References}

1. J. M. Margolis. Engineering plastics handbook. Montreal: The McGraw-Hill Companies, Inc. (2006). p.77.

https://epdf.tips/engineering-plastics-handbook-mcgraw-hill-handbooks.html

2. Y. Beauchamp, M. Thomas, Y.A. Youssef, J. Masounave, J. Computers and Industrial Engineering, 31,3-4:645-651(1996).

https://www.researchgate.net/publication/232394599 Investigation of cutting parame ter_effects_on_surface_roughness_in_lathe_boring_operation_by_use_of_a full_facto rial design

3. G. Vohra, P. Singh, H.S. Sodhi, NCRAET:232-237(2013). http://ijcsce.in/wp-content/uploads/2013/06/IJCSCESI045513.pdf

4. M.P. Vaishnav and S.A. Sonawane, IJERT, 3,8:717-721(2014). https://www.ijert.org/research/optimization-of-boring-process-parameters-by-usingtaguchi-method-IJERTV3IS080601.pdf

5. P.M. Borade and M.J. Deshmukh, IJERT, 3,3:1099-1101(2014). https://www.ijert.org/research/optimization-of-process-parameters-in-boring-operationa-review-IJERTV3IS030803.pdf

6. P. Kumar, J.S. Oberoi, C. Singh, H. Dhiman, International Journal of Advanced Mechanical Engineering, 4,6:647-655(2014).

https://www.ripublication.com/ijame-spl/ijamev4n6spl_08.pdf

7. T. Panyaphirawat, P. Sapsmarnwong, T. Pornyungyuen, International Journal of Industrial and Manufacturing Engineering, 8,9:1516-1520(2014).

https://waset.org/publications/9999236/an-optimization-of-machine-parameters-formodified-horizontal-boring-tool-using-taguchi-method

8. C. Chennu, V.S. Nitish, A.S. Kumar, K.B. Narayana, J. Moghaveera, IJRET, 5,13 (2016). https://ijret.org/volumes/2016v05/i25/IJRET20160525031.pdf

9. L. Rico, S. Noriega, J.L. García, E.A. Martínez, R. Ñeco, F.J. Estrada, Journal of applied research and technology, 8,3:395-403(2010).

https://www.researchgate.net/publication/262476081 Effect of the Side CuttingEdge Angle on the Surface Roughness for_Aluminum 1350 in the Turning Oper ation by Taguchi_Method

10. R. Mohammad, M.K.A.M. Ariffin, B.H.T. Baharuddin, F. Mustapha, H. Aoyama, Journal of Mechanical Engineering, 3,1:45-54(2017). https://jmeche.uitm.edu.my/wpcontent/uploads/bsk-pdf-manager/5 SI Vol 3 1 ID012 105.pdf

11. Z.A. Karim, S.A.S Azuan, A.Y.M.S., Australian Journal of Basic and Applied Sciences, 7,10:46-51 (2013).

https://ir.unikl.edu.my/jspui/bitstream/123456789/7375/1/A\%20Study\%20on\%20Tool \%20Wear $\% 20$ and $\% 20$ Surface $\% 20$ Finish $\% 20$ by $\% 20$ Applying $\% 20$ Positive $\% 20$ and $\% 2$ 0Negative $\% 20$ Rake $\% 20$ angle.pdf

12. L. Setiawati. Studi tentang parameter - parameter yang berpengaruh untuk menghasilkan laju pemakanan material dan kekasaran permukaan yang optimum pada pemesinan polyacetal. 
[Study on influenced parameters to achieve optimum material removal rate and surface roughness on polyacetal machining] [Thesis] Teknik Manufaktur, Universitas Surabaya (2004). [in Bahasa Indonesia]. p. IV-1 - IV-48 [Online] from http://digilib.ubaya.ac.id/data pustaka-134748.html [Acessed on 11 January 2018]

13. A. Sugiantoro. Studi geometri pahat, parameter pemesinan dan cairan pendingin untuk optimalisasi performasi pemesinan polyacetal. [A study on tool geometry, machining parameters, and coolant to optimize the performance of polyacetal machinig] [Thesis] Teknik Manufaktur, Universitas Surabaya (2004). [in Bahasa Indonesia]. p. IV-1 - IV35 [Online] from http://digilib.ubaya.ac.id/data pustaka-134824.html [Acessed on 11 January 2018]

14. S. Kalpakjian. Manufacturing engineering and technology. 7th ed. Massachusets: Addison-Weasley Publishing Company, Inc. (2013). p. 625 - 667

https://www.academia.edu/36063951/Manufacturing Manufacturing Engineering and _Technology_SI_by_Serope_Kalpakjian_7th_Pearson_2013_1 